\title{
Pendidikan Kesehatan Media Booklet Mengurangi Kecemasan Ibu pada Imunisasi Dasar di Era Pandemi Covid-19
}

\author{
Health Education Media Booklet Reduce Baby Mother's Anxiety in The \\ Provision of Immunization in The Era of The Covid-19 Pandemic
}

\author{
Mestika Lumbantoruan ${ }^{1}$, Asima Sirait ${ }^{2}$, Juneris Aritonang ${ }^{3}$, Kristimone Andayani ${ }^{4}$ \\ 1,2,3,4 Universitas Sari Mutiara Indonesia \\ 1Email: tikatoruan@yahoo.com
}

\begin{abstract}
ABSTRAK
Pandemi Covid-19 merubah tata cara kebiasaan termasuk menyebabkan gangguan dalam program imunisasi rutin. Awal pandemi Covid-19 di Indonesia pelayanan posyandu sempat terhenti dan akhirnya pada pelaksanaan aktifitas pelayanan imunisasi didapatkan terjadi penurunan. Data dari pemerhati imunisasi anak ditemukan bahwa $83,9 \%$ pelayanan imunisasi terganggu karna pandemi Covid19 hasil survei cepat ini dilakukan dilapangan pada bulan april 2020. Salah satunya faktor penyebabnya adalah adanya rasa kekhawatiran dan ketakutan ibu terinfeksi Covid-19 di fasilitas kesehatan termasuk posyandu. Perlu suatu pendidikan guna merubah perilaku individu yang lebih baik tentang hal ini. Penelitian ini bertujuan untuk menganalisis pendidikan kesehatan dengan booklet terhadap kecemasan ibu pada pemberian imunisasi dasar di era pandemi Covid-19. Desain penelitian ini menggunakan quasy eksperimental, analisa data menggunakan uji statistik Mc. Nemar. Hasil penelitian ada pengaruh pemberian pendidikan kesehatan dengan media booklet terhadap kecemasan ibu bayi 0-12 bulan dalam pemberian imunisasi di era pandemic covid-19 di Kelurahan Pekan Tanjung Morawa tahun 2021 dengan p-value 0.015 . Terdapat penurunan jumlah responden yang cemas rigan dari $65 \%$ menjadi $33 \%$, dan tidak ditemukan lagi responden dengan tingkat cemas sedang. Jumlah responden yang tidak cemas bertambah 39 orang. Hasil penelitian ini perlu dilakukan penyuluhan secara holistik terkait imunisasi selama pandemi maupun lainnya menggunaka booklet.
\end{abstract}

Kata kunci: Imunisasi, Kecemasan Ibu, Media Booklet, Pandemic Covid-19, Pendidikan Kesehatan

\begin{abstract}
The Covid-19 pandemic has changed customary procedures, including causing disruptions in routine immunization programs. At the beginning of the Covid-19 pandemic in Indonesia, posyandu services had stopped and finally, during the implementation of immunization service activities, there was a decline. Data from observers of child immunization found that $83.9 \%$ of immunization services were disrupted due to the Covid-19 pandemic, the results in April 2020. One of factors was the feeling of worry and fear of mothers being infected with Covid-19 in health facilities including posyandu. . An education is needed to change the behavior of individuals for the better on this matter. This study aims to analyze health education with booklets on maternal anxiety in providing basic immunization in the era of the Covid-19 pandemic. The design of this study used a quasi-experimental, data analysis using the Mc. Nemar. The results, there was an effect of providing health education with booklet media on the anxiety of mothers of babies 0-12 months in giving immunizations in the era of the covid-19 pandemic in the Desa Pekan Tanjung Morawa in 2021 with a p-value 0.015. There was a decrease in the number of respondents with mild anxiety from $65 \%$ to $33 \%$, and no more respondents with moderate anxiety levels were found. The number of respondents who were not anxious increased by 39 people. The results of this study need to be carried out holistically related to immunization during the pandemic and others using booklets.
\end{abstract}

Keywords: Immunization, Maternal Anxiety, Media Booklets, The Covid-19 Pandemic, Health Education 


\section{PENDAHULUAN}

Dampak negatif Covid-19 menyebabkan angka kesakitan hingga kematian terjadi peningkatan di dunia dan merubah tatanan faktor kesehatan dan faktor lainnya. Selain itu pandemi Covid-19 merubah tata cara kebiasaan termasuk menyebabkan gangguan dalam program imunisasi rutin (Saxena et al., 2020). Terjadi penurunan imunisasi bayi dan anak tepat waktu secara global dan di Kanada dan Amerika Serikat (McDonald et al., 2020). Tantangan baru dirasakan oleh petugas kesehatan saat ini adalah terkait penyediaan, mempertahankan dan memperkuat pemberian imunisasi dasar secara lengkap (McNally \& Bernstein, 2020).

Pada awal pandemi Covid-19 di Indonesia kegiatan posyandu sempat terhenti dan akhirnya pada pelaksanaan aktifitas pelayanan imunisasi didapatkan terjadi penurunan. Pelayanan imunusasi seharusnya menjadi kegiatan yang tetap berjalan dan tidak kalah pentingnya dengan pelayanan pencegahan maupun penanganan kasus Covid-19 dikarenakan imunisasi merupakan pelayanan yang mendasar dan utama dalam pelaksanaannya. Hal tersebut dikarenakan bayi dan balita berada di tahap awal kehidupannya, melalui pemantauan tumbuh kembang dan imunisasi dapat meningkatkan daya tahan tubuh anak pengontrolan tumbuh kembang bayi balita sebagai identifikasi derajat kesehatan (Direktur Jenderal Pencegahan dan Pengendalian Penyakit Kemenkes RI, 2020)

Hal berikutnya didapati pelayanan imunisasi tidak dilaksanakan hampir di sejumlah wilayah di Indonesia dikarenakan beberapa fator diantaranya pembatasan social beskala besar (PSBB).

Selain faktor PSBB, rendahnya cakupan imunisasi disebabkan adanya rasa kekhawatiran dan ketakutan ibu ke fasilitas kesehatan termasuk posyandu . Dibuktikan dalam penelitian sebelumnya dalam penelitian (Aritonang, 2020) didapati ibu yang memiliki balita memiliki kecemasan yang tinggi membawa balitanya ke posyandu. Kecemasan tersebut disebabkan kurangnya pengetahuan dalam pencegahan terinfeksi COVID19.

Seluruh lapisan masyarakat mengalami stress sejak munculnya informasi terkait Covid-19 (McDonald et al., 2020). Walaupun Ibu yang 
memiliki balita khawatir untuk datang kefasilitas kesehatan tetapi diera pandemi Covid-19 ini pelaksanaan imunisasi tetap berlangsung dengan prinsip dan protokol kesehatan (Prihati et al., 2020).

Adanya anggapan resiko terinfeksi lebih besar juga dapat meningkatkan kecemasan. Wilayah kerja Kelurahan Pekan Tanjung Morawa tercatat penyumbang kasus positif Covid-19. Kecemasan tinggi inilah menjadi salah satufaktor penyebab rendahnya kunjungan posyandu oleh ibu dan balita. Hal ini menunjukkan bahwa masyarakat belum beradaptasi sehingga dibutuhkan suatu inovasi terciptanya secara teknis posyandu yang dirasa aman di situasi Covid-19 serta dibutuhkan kegiatan yang bersifat promosi kesehatan yang mampu merubah perilaku masyarakat (peningkatan pengetahuan, sikap dan perilaku). Hasil penelitian sebelumnya (Aritonang, 2018) didapati pemberian pendidikan/promosi kesehatan yang optimal diberikan ke ibu yang memiliki bayi balita, cakupan imunisasi pentabio lanjutan mengalami peningkatan.

Dari survey awal yang dilakukan di Kelurahan Pekan Tanjung Morawa didapati penurunan cakupan imunisasi hinga $40 \%$ dan dilakukan wawancara kepada 5 ibu bayi berusia 0-12 bulan, hanya 2 ibu masih rutin membawa balitanya untuk posyandu. Dan selurh ibu tersebut mengatakan was-was pada saat membawa balitanya ke posyandu. Empat orang diantaranya masih berpengetahuan kurang tentang bagaimana cara mencegahan terinfeksi Covid-19 pada saat posyandu di masa pandemi Covid-19. Mereka mengatakan sudah pernah mengikuti penyuluhan pencegahan tertularnya Covid-19 tetapi karena bersifat penyuluhan saja tanpa ada diberi leafleat atau buku yang dibaca-baca sehingga materi yang diberikan tidak diingat secara detail. Penurunan cakupan/layanan imunisasi dapat menyebabkan krisis kesehatan tambahan yang meningkatkan morbiditas hingga mortalitas (kejadian luar biasa/KLB PD3I) (Chandir et al., 2020).

Dari uraian tersebut, maka penulis tertarik ingin melakukan penelitian dengan judul "pengaruh pendidikan kesehatan dengan media booklet terhadap kecemasan ibu bayi 012 bulan dalam pemberian imunisasi di era pandemi Covid-19 di Kelurahan Pekan Tanjung Morawa tahun 2021” 


\section{METODE PENELITIAN}

Desain penelitian ini menggunakan analitik pendekatan quasy eksperimental dengan one group pre- post test. Penelitian ini dilakukan di Kelurahan Pekan Tanjung Morawa Kabupaten Deli Serdang dengan waktu penelitian September 2020-Maret 2021. Populasi dalam penelitian ini seluruh ibu bayi 0-12 bulan di Kelurahan Pekan Tanjung Morawa sejumlah 80 orang. Sampel diambil dengan teknik sample random sampling berjumlah 66 orang.

Penelitian ini diawali dengan tahap pre-test (responden mengisi kuesioner selama \pm 10 menit), tahap selanjutnya adalah pelaksanaan pendidikan kesehatan berupa pendidikan kesehatan dengan media booklet.

Mengukur tingkat kecemasan peneliti menggunakan kuesioner HARS (Hamilton Rating Scale of Anxiety) dengan sistem skoring, yaitu: Skor $0=$ tidak ada gejala; skor 1 = ringan (satu gejala); skor 2 = sedang (dua gejala); skor 3 = berat (lebih dari dua gejala); skor 4 = sangat berat (semua gejala).

$$
\text { Pendidikan kesehatan }
$$

berlangsung selama 60 menit yang terdiri dari ceramah, tanya jawab dan memberikan booklet ke seluruh responden. Tahap terakhir adalah melakukan post-test untuk mengukur kecemasan setelah dilakukan pemberian pendidikan kesehatan. Analisa data menggunakan uji statistik Mc. Nemar.

\section{HASIL DAN PEMBAHASAN}

Kelurahan Pekan tanjung Morawa tidak jauh dari lokasi ibu kota Kabupaten Deli serdang. Puskesmas induk berada di kelurahan tempat lokasi penelitian ini. Selain puskesmas, kelurahan Pekan Tanjung Morawa memiliki 4 posyandu yang sebelum pandemi Covid-19 terlaksana dengan rutin dan berjalan dengan baik.

Pada masa pandemi, terjadi penurunan kunjungan ke posyandu yang ada, walaupun sudah dilakukan pengkaderan dan penginformasian akan jadwal posyandu ke masing-masing rumah keluarga yang memiliki balita.

Hasil penelitian menunjukkan adanya perubahan tingkat kecemasan ibu yang memiliki bayi 0-12 bulan (pre dan post intervensi) dalam pemberian imunisasi di era pandemi Covid-19 di Kelurahan Pekan Tanjung Morawa setelah intervensi.

$\begin{array}{rrr}\text { Sebelum } & \text { dilakukan } & \text { intervensi } \\ \text { menggunakan } & \text { booklet } & \text { data } \\ \text { menunjukkan } & \text { mayoritas } & \text { responden }\end{array}$


memiliki kecemasan ringan $(65.1 \%)$, hanya $7,6 \%$ responden yang merasa tidak cemas dan ditemukan $27.3 \%$ ibu pada kecemasan sedang. Setelah dilakukan intervensi terjadi perubahan yakni mayoritas responden merasa tidak cemas lagi $(66.7 \%)$ dan $33.3 \%$ adalah kecemasan ringan. Tidak ditemukan lagi responden dengan kecemasan sedang.

Tabel 1. Tabulasi data uji Mc. Nemar pengaruh pendidikan kesehatan dengan media booklet terhadap kecemasan ibu bayi 0-12 bulan dalam pemberian imunisasi di era pandemi Covid-19 di Kelurahan Pekan Tanjung Morawa tahun 2021

\begin{tabular}{|c|c|c|c|c|c|c|c|c|c|c|c|c|c|c|}
\hline \multirow{2}{*}{\multicolumn{2}{|c|}{ Kecemasan }} & \multicolumn{2}{|c|}{$\begin{array}{c}\text { Tidak } \\
\text { Cemas }\end{array}$} & \multicolumn{2}{|c|}{$\begin{array}{l}\text { Cemas } \\
\text { Ringan }\end{array}$} & \multicolumn{2}{|c|}{$\begin{array}{l}\text { Post test } \\
\text { Cemas } \\
\text { Sedang }\end{array}$} & \multicolumn{2}{|c|}{$\begin{array}{c}\text { Cemas } \\
\text { Berat }\end{array}$} & \multicolumn{2}{|c|}{ Panik } & \multicolumn{2}{|c|}{ Total } & \multirow[t]{2}{*}{$p$-value } \\
\hline & & $\mathrm{F}$ & $\%$ & $\mathrm{~F}$ & $\%$ & $\mathrm{~F}$ & $\%$ & $\mathrm{~F}$ & $\%$ & $\mathrm{~F}$ & $\%$ & $\mathrm{~F}$ & $\%$ & \\
\hline \multirow{6}{*}{$\begin{array}{l}\text { Pre } \\
\text { test }\end{array}$} & $\begin{array}{l}\text { Tidak } \\
\text { cemas }\end{array}$ & 5 & 7.6 & 0 & 0 & 0 & 0 & 0 & 0 & 0 & 0 & 5 & 7.6 & \multirow{6}{*}{0.015} \\
\hline & $\begin{array}{l}\text { Cemas } \\
\text { ringan }\end{array}$ & 39 & 59 & 4 & 6.1 & 0 & 0 & 0 & 0 & 0 & 0 & 43 & 65.1 & \\
\hline & $\begin{array}{l}\text { Cemas } \\
\text { sedang }\end{array}$ & 0 & 0 & 18 & 27 & 0 & 0 & 0 & 0 & 0 & 0 & 18 & 27.3 & \\
\hline & $\begin{array}{l}\text { Cemas } \\
\text { berat }\end{array}$ & 0 & 0 & 0 & 0 & 0 & 0 & 0 & 0 & 0 & 0 & 0 & 0 & \\
\hline & Panic & 0 & 0 & 0 & 0 & 0 & 0 & 0 & 0 & 0 & 0 & 0 & 0 & \\
\hline & Total & 44 & 67 & 22 & 33 & 0 & 0 & 0 & 0 & 0 & 0 & 66 & 100 & \\
\hline
\end{tabular}

Tabel di atas menunjukkan pendidikan kesehatan dengan media booklet berpengaruh terhadap kecemasan ibu bayi 0-12 bulan dalam pemberian imunisasi di era pandemi Covid-19 di Kelurahan Pekan Tanjung Morawa tahun 2021, p-value 0.015 ( $p$ value $<0.05)$.

Hasil penelitian didapati terdapat perubahan yang signifikan setelah dilakukan pendidikan kesehatan media booklet. Hal ini tampak pada tingkat kecemasan responden mayoritas kecemasan ringan (65\%) sebelum dilakukan pendidikan kesehatan menurun menjadi $33 \%$. Tidak lagi ditemukan responden dengan kecemasan sedang yang sebelum pendidikan kesehatan sebesar 27.3\%), terjadi peningkatan sebesar 39 responden yang tidak cemas.

(Notoatmodjo, 2011) menungkapkan bawa landasan terpenting suatu tindakan hingga perilaku adalah pengetahuan. Hal tersebut juga berlaku pada perilaku kesehatan, dibutuhkan pengetahuan, sikap, dan tindakan dalam pengambilan keputusan. Seseorang berpengetahuan baik akan berupaya menerapkan yang diketahuinya tersebut di dalam 
kesehariannya. Domain terpenting dalam pembentukan suatu tindakan seseorang (overt behavior) hingga menjadikan suatu kebiasaan adalah pengetahuan.

Kemampuan seseorang dalam menentukan perilaku yang baik menurutnya didasari pengetahuan yang dimilikinya. Ada atau tidaknya pengetahuan dalam diri seseorang mempengaruhi penyerapan hingga pemahaman informasi kesehatan.

Upaya penyampaian informasi kesehatan kepada masyarakat merupakan upaka pendidikan/promosi kesehatan dengan tujuan peningkatan pengetahuan menjadi lebih baik. Pengetahuan tersebut pada akhirnya diharapkan dapat berpengaruh terhadap perubahan perilaku (Notoatmodjo, 2011)

Penelitian ini mengungkapkan pengetahuan ibu tentang pemberian imunisasi di era pandemi Covid-19 dapat meningkat dipengaruhi oleh pendidikan kesehatan. Pengetahuan yang meningkat tersebut juga mempengaruhi tingkat kecemasan. Kecemasan berkurang juga antara sebelum dan sesudah pendidikan kesehatan.
Hasil penelitian ini sesuai dengan hasil penelitian yang dilakukan sebelumnya, penurunan tingkat kecemasan pasien yang akan dioperasi setelah dilakukan informasi sebelum tindakan operasi katarak (Rondonuwu et al., 2014)

Selain itu, kecemasan yang muncul disebabkan informasi tentang Covid-19 yang masih belum jelas. Kurangnya pengetahuan terbaru terkait Covid-19 dapat mengakibatkan kekhawatiran (Yao et al., 2020).

Kondisi emosi psikologis seseorang individu dapat berupa tegang, gelisah, khawatir, perasaan terancam hingga rasa takut yang disebabkan ketidakpastian sesuatu yang buruk akan terjadi merupakan ciri-ciri suatu kecemasan (anxiety). Kecemasan juga merupakan penyebab suatu tindakan antisipasi dari bahaya ataupun dapat sebagai sinyal yang dapat membantu seseorang sebagai persiapan pengambilan tindakan. 


\section{SIMPULAN DAN SARAN}

Ada pengaruh pendidikan kesehatan dengan media booklet terhadap kecemasan ibu yang memiliki bayi 0-12 bulan dalam pemberian imunisasi di era pandemi Covid-19 di Kelurahan Pekan Tanjung Morawa tahun 2021 ( $p$-value 0.015).

Diharapkan melalui pendidikan kesehatan dengan media booklet yang diberikan dalam penelitian ini dapat meningkatkan perilaku responden dalam membawa bayinya imunisasi dan posyandu di masa pandemi Covid-19 responden dapat lebih meningkatkan wawasan tentang imunisasi aman di masa pandemi ini melalui fasilitas tenaga kesehatan, ataupun buku-buku yang ada sehingga mau melakukan pemberian imunisasi hingga imunisasi.

Tenaga kesehatan yang bertugas di Kelurahan Pekan Tanjung Morawa tahun diharapkan adanya peningkatan kualitas pelayanan yang baik bagi masyarakat terutama di dalam promosi, konseling serta penyuluhan kesehatan terkait pentingnya imunisasi di pandemi Covid-19 yang tujuan akhirnya adalah peningkatan cakupan imunisasi dasar dan lanjutan di masa pandemi Covid-19.

Perlu dilakukan penelitian selanjutnya untuk melakukan penelitian perbandingan keefektifitasan pendidikan kesehatan menggunakan media booklet dengan media pendidikan kesehatan lainnya.

\section{DAFTAR PUSTAKA}

Aritonang, J. (2018). Peningkatan Pengetahuan Ibu Tentang Imunisasi Pentabio Lanjutan Setelah Pemberian Pendidikan Kesehatan Di Puskesmas Lampaseh Aceh. Jurnal Riset Kesehatan Nasional, 2(2), 173179. https://doi.org/10.37294/jrkn.v2 i2. 125

Aritonang, J. (2020). KECEMASAN PANDEMI COVID-19 DALAM KEIKUTSERTAAN POSYANDU DI KELURAHAN PEKAN TANJUNG MORAWA TAHUN 2020. Health Reproductive, 5(1), 1-6. file:///C:/Users/Juneris Aritonang/Downloads/1426Article Text-4695-1-1020201028 (1).pdf

Chandir, S., Siddiqi, D. A., Mehmood, M., Setayesh, H., Siddique, M., Mirza, A., Soundardjee, R., Dharma, V. K., Shah, M. T., Abdullah, S., Akhter, M. A., Ali Khan, A., \& Khan, A. J. (2020). Impact of COVID-19 pandemic response on uptake of routine immunizations in Sindh, Pakistan: An analysis of provincial electronic immunization registry data. Vaccine. https://doi.org/10.1016/j.vaccin e.2020.08.019 
Direktur Jenderal Pencegahan dan Pengendalian Penyakit Kemenkes RI. (2020). Petunjuk Teknis Pelayanan Imunisasi Pada Masa Pandemi COVID19.

McDonald, H. I., Tessier, E., White, J. M., Woodruff, M., Knowles, C., Bates, C., Parry, J., Walker, J. L., Scott, J. A., Smeeth, L., Yarwood, J., Ramsay, M., \& Edelstein, M. (2020). Early impact of the coronavirus disease (COVID-19) pandemic and physical distancing measures on routine childhood vaccinations in England, January to April 2020. Eurosurveillance, 25(15), 1-6.

McNally, V. V., \& Bernstein, H. H. (2020). The Effect of the COVID-19 Pandemic on Childhood Immunizations: Ways to Strengthen Routine Vaccination. Pediatric Annals. https://doi.org/10.3928/1938235 9-20201115-01

Notoatmodjo, S. (2011). Kesehatan masyarakat ilmu dan seni (Revisi 201). PT. Rineka Cipta. http://repo.unikadelasalle.ac.id/i ndex.php?p=show_detail\&id=6 689\&keywords $=$
Prihati, D. R., Wirawati, M. K., \& Supriyanti, E. (2020). Analisis Pengetahuan Dan Perilaku Masyarakat Di Kelurahan Baru Kotawaringin Barat Tentang Covid 19. Malahayati Nursing Journal. https://doi.org/10.33024/manuju .v2i4.3073

Rondonuwu, R., Moningka, L., \& Patani, R. (2014). Hubungan Pengetahuan dengan Tingkat Kecemasan Pada Klien Pre Operasi Katarak Di Balai Kesehatan Mata Masyarakat (BKMM) Manado. Jurnal Ilmiah Perawat Manado, 3(2), 27-31.

Saxena, S., Skirrow, H., \& Bedford, H. (2020). Routine vaccination during covid-19 pandemic response Falls in uptake must be reversed quickly. The $B M J$, $39,1-2$.

Yao, H., Chen, J. H., \& Xu, Y. F. (2020). Rethinking online mental health services in China during the COVID-19 epidemic. In Asian Journal of Psychiatry. https://doi.org/10.1016/j.ajp.202 0.102015 